\title{
Chemoradiotherapy in the Management of Cardiac Metastases: A Case Report and Brief Review
}

\author{
Gonca ALTINIŞIK INAN,' (1) Karabekir ERCAN, ${ }^{2}$ (1) Ijpek PInar ARAL, ${ }^{3}$ (1) Süheyla AYTAÇ ARSLAN, ${ }^{1}$ \\ Hüseyin Furkan ÖZTÜRK, ${ }^{1}$ (D) YIImaz TEZCAN ${ }^{1}$
}

\author{
'Department of Radiation Oncology, Ankara Yıldırım Beyazıt University Faculty of Medicine, Ankara-Turkey \\ 2Department of Radiology, Ankara City Hospital, Ankara-Turkey \\ ${ }^{3}$ Department of Radiation Oncology, Nevşehir State Hospital, Ankara-Turkey
}

\section{Dear Editor,}

Metastatic cardiac tumors are rare clinical situations; however, its incidence increases due to the increment in survival of cancer patients and improvement in imaging techniques.[1] The incidence of cardiac metastasis data was mostly obtained from autopsy series. The incidence rates vary from 1.5 to $25 \%$.[2,3] All cancers have the potential for cardiac metastasis. Tumors with the highest tendency to metastasize to the heart are melanomas, mesotheliomas, and mediastinal malignancies.[4,5] Although the pericardium is the most frequently involved site, the development of metastasis could be observed in other structures of the heart.[4,6] There are 4 different ways defined for the development of cardiac metastasis: Hematological, lymphatic, transvenous, and direct invasion. $[7,8]$ Cardiac metastasis development pathway may also be determinative in the gotten hold of cardiac structure.

Lung cancers have a high tendency to metastasis and are among the primary cancers that metastasize to the heart. Cardiac metastases are not considered in the differential diagnosis since their different presentations. In the selection of treatment, the presence of symptoms, the control status of the primary tumor and the involved cardiac region are determinant and there is no standard treatment.

In this study, we present a patient with cardiac metastases treated with chemoradiotherapy (CRT) and reviewed the literature.

We searched the PubMed database (National Library of Medicine, http://www.ncbi.nlm.nih.gov) be- tween 1984 to May 2020, using the search words "cardiac metastasis," "radiotherapy," "chemoradiotherapy," and "metastatic cardiac tumors." The studies about patients with cardiac metastases treated through RT, with treatment details available, written in English were included in the study. The 7 case reports (Table 1) and 2 case series were identified.

A 63-year-old male patient was admitted to the outer center with the complaint of dyspnea at October 2017. The thorax angio-computed tomography (CT) was applied to the patient and a $40 \times 30 \mathrm{~mm}$ mass that invading the right main pulmonary artery distal, lobar branches, right upper pulmonary vein, and atrium was reported in the right lung. The mass was evaluated by bronchoscopic biopsy and the pathology result was reported as pulmonary squamous cell carcinoma. No additional spreading/metastasis area was seen after the staging evaluations. The patient underwent a right extended pneumonectomy after neoadjuvant 3 cycles of gemcitabine-cisplatin chemotherapy. In the pathological examination, a $4.3 \mathrm{~cm}$ lesion that invading the visceral pleura and 3 metastatic lymph nodes located in the perihilar region and 1 reactive lymph node were reported. No data on atrium invasion was found in the pathology report. The patient was treated with adjuvant 2 cycles of cisplatin + navelbine and the patient was followed up. The patient received radio-ablation therapy due to liver metastasis detected in December 2018. The positron emission tomography (PET)-CT was performed in March 2019 with the patient complaining of back pain/ dyspnea. Pathologically increased standardized uptake values (SUV) were detected in a $2.5 \mathrm{~cm}$ mass in the right 
Table 1 Radiotherapy in the treatment of cardiac metastases: Case reports

\begin{tabular}{|c|c|c|c|c|c|c|c|c|c|}
\hline Study & $\begin{array}{l}\text { Patient } \\
\text { age(yo) }\end{array}$ & $\begin{array}{l}\text { Primary } \\
\text { cancer }\end{array}$ & Symptom & $\begin{array}{l}\text { Imaging } \\
\text { of } \\
\text { recurrence }\end{array}$ & $\begin{array}{l}\text { Cardiac } \\
\text { subunit }\end{array}$ & $\begin{array}{l}\text { Intent } \\
\text { of } \\
\text { radiotherapy }\end{array}$ & $\begin{array}{l}\text { Radiotherapy } \\
\text { total dose } \\
\text { (Gy)/ fraction }\end{array}$ & $\begin{array}{l}\text { Concurrent } \\
\text { chemotherapy }\end{array}$ & Outcome \\
\hline $\begin{array}{l}\text { Jumeau } \\
\text { et al., } \\
2019[16]\end{array}$ & 66 & $\begin{array}{l}\text { Lung } \\
\text { cancer }\end{array}$ & Syncope & MRI & Inferior IVS & Curative & $20 \mathrm{~Gy} / 1 \mathrm{frc}$ & No & $\begin{array}{l}\text { Clinical and } \\
\text { radiological } \\
\text { complete } \\
\text { response at } 3 \mathrm{~m}\end{array}$ \\
\hline $\begin{array}{l}\text { Frakulli } \\
\text { et al., } \\
2017[17]\end{array}$ & 32 & $\begin{array}{l}\text { Spindle cell } \\
\text { sarcoma }\end{array}$ & $\begin{array}{l}\text { Dyspnea, } \\
\text { general } \\
\text { fatigue }\end{array}$ & MRI & $\begin{array}{l}\text { IVS, right } \\
\text { ventricle }\end{array}$ & Palliative & $25 \mathrm{~Gy} / 5 \mathrm{frc}$ & No & $\begin{array}{l}\text { Complete clinical } \\
\text { response at } 1 \mathrm{~m}\end{array}$ \\
\hline $\begin{array}{l}\text { Lee and } \\
\text { Kishan, } \\
\text { 2012[18] }\end{array}$ & 63 & $\begin{array}{l}\text { Lung } \\
\text { cancer }\end{array}$ & Hemoptysis & CT & Left atrium & Palliative & $50 \mathrm{~Gy} / 20 \mathrm{frc}$ & No & $\begin{array}{l}\text { Clinical complete } \\
\text { response Partial } \\
\text { radiological } \\
\text { response at } 3 \mathrm{~m}\end{array}$ \\
\hline $\begin{array}{l}\text { Dasgupta } \\
\text { et al., } \\
2011[19]\end{array}$ & 80 & $\begin{array}{l}\text { Anaplastic } \\
\text { thyroid } \\
\text { cancer }\end{array}$ & $\begin{array}{l}\text { Orthostatic } \\
\text { hypotension }\end{array}$ & CT & $\begin{array}{l}\text { Right atrium, } \\
\text { right } \\
\text { ventricle }\end{array}$ & Palliative & $37.5 \mathrm{~Gy} / 15 \mathrm{frc}$ & $\begin{array}{l}\text { Paclitaxel } \\
\left(50 \mathrm{mg} / \mathrm{m}^{2}\right. \\
\text { on days } 1 \\
\text { and } 8 \text { of RT }\end{array}$ & $\begin{array}{l}\text { Clinical and } \\
\text { radiological } \\
\text { partial responce } \\
\text { at } 1 \mathrm{~m}\end{array}$ \\
\hline $\begin{array}{l}\text { Al-Mamgar } \\
\text { et al., } \\
2008[2]\end{array}$ & & $\begin{array}{l}\text { Esophageal } \\
\text { cancer }\end{array}$ & $\begin{array}{l}\text { Atypical } \\
\text { chest pain }\end{array}$ & $\mathrm{CT}$ & $\begin{array}{l}\text { Right } \\
\text { ventricle }\end{array}$ & Palliative & $20 \mathrm{~Gy} / 5 \mathrm{frc}$ & No & $\begin{array}{l}\text { Subjective clinical } \\
\text { relief at } 3 w\end{array}$ \\
\hline $\begin{array}{l}\text { Fukuda } \\
\text { et al., } \\
2000[20]\end{array}$ & 62 & $\begin{array}{l}\text { Papillary } \\
\text { thyroid } \\
\text { carcinoma }\end{array}$ & $\begin{array}{l}\text { Chest pain, } \\
\text { dyspnea on } \\
\text { effort, } \\
\text { pretibial } \\
\text { edema }\end{array}$ & $\mathrm{CT}$, echo & $\begin{array}{l}\text { Both } \\
\text { ventricles }\end{array}$ & Palliative & $12 \mathrm{~Gy} / 6 \mathrm{frc}$ & No & $\begin{array}{l}\text { Sudden death at } \\
\text { the } 6^{\text {th }} \text { day of RT }\end{array}$ \\
\hline $\begin{array}{l}\text { Yamana } \\
\text { et al., } \\
2004[21]\end{array}$ & 54 & $\begin{array}{l}\text { Merkel cell } \\
\text { carcinoma }\end{array}$ & No symptoms & s MRI & $\begin{array}{l}\text { Interatrial } \\
\text { septum and } \\
\text { right atrium }\end{array}$ & Palliative & $43 \mathrm{~Gy} / 19 \mathrm{frc}$ & No & $\begin{array}{l}\text { Clinical and } \\
\text { radiological } \\
\text { partial response }\end{array}$ \\
\hline $\begin{array}{l}\text { Current } \\
\text { study }\end{array}$ & 63 & Lung cancer & $\begin{array}{l}\text { Back pain/ } \\
\text { dyspnea }\end{array}$ & MRI & $\begin{array}{l}\text { Right atrium } \\
\text { and interatrial } \\
\text { septum }\end{array}$ & Curative & $46 \mathrm{~Gy} / 23 \mathrm{frc}$ & $\begin{array}{l}\text { Paclitaxel } \\
45 \mathrm{mg} / \mathrm{m}^{2} / \\
\text { hafta- } \\
\text { carboplatin auc) } \\
4 \text { cycle } 4 \text { cycle }\end{array}$ & $\begin{array}{l}\text { Partial radiological } \\
\text { regression at } 2 \mathrm{~m}\end{array}$ \\
\hline
\end{tabular}

CT: Computed tomography; MRI: Magnetic resonance Imaging; frc: fraction; echo: echocardiography; IVS: Interventricular septum

hemithorax at the T8 vertebra level. Then, the patient underwent 3 cycles of gemcitabine-cisplatin chemotherapy. In PET-CT examination performed for response evaluation at July 19 , it was observed that the lesion persisted despite the partial decrease in the SUV of the mass (Fig. 1). The patient was referred to our clinic to evaluate the indication of RT. The patient's images were evaluated together with the radiologist and upon the suspicion of cardiac involvement, it was decided to conduct further examination with cardiac magnetic resonance imaging (MRI). In the MRI examination, a size of $38 \times 23 \mathrm{~mm}$ mass lesion that spreads to the interatrial septum and the posterior wall of the left atrium, reaching a wall thickness of $18 \mathrm{~mm}$ at the IAS level, preventing significant wall movement at its present level, isointense with the myocardium on T1W examination, hyperintense signal characteristic of STIR examination, showing heterogeneous opacification pattern after IV infusion, was reported. It is differentiated from myxoma and thrombus due to its presence in the wall. Intrawall rhabdomyoma was ruled out due to the patient's advanced age. Lipoma and teratoma have been ruled out due to the lack of fat content. On the other hand, the decrease in SUV involvement of the tumor detected in PET-BT after chemotherapy brought us closer to the idea of being metastasis of this lesion. The patient who had not additional metastasis was evaluated by cardiovascular surgery and he was not considered suitable for surgery. Before the treatment decision, the patient was consulted to the cardiology clinic for cardiological examination and follow-up. In the examination performed in the cardiology clinic, the patient whose pathological finding was not reported, ejection fraction was reported as $55 \%$ in echocardiography, and it was stated that the mass image was not observed. It was recommended that the follow-up of the patient should be done with cardiac 

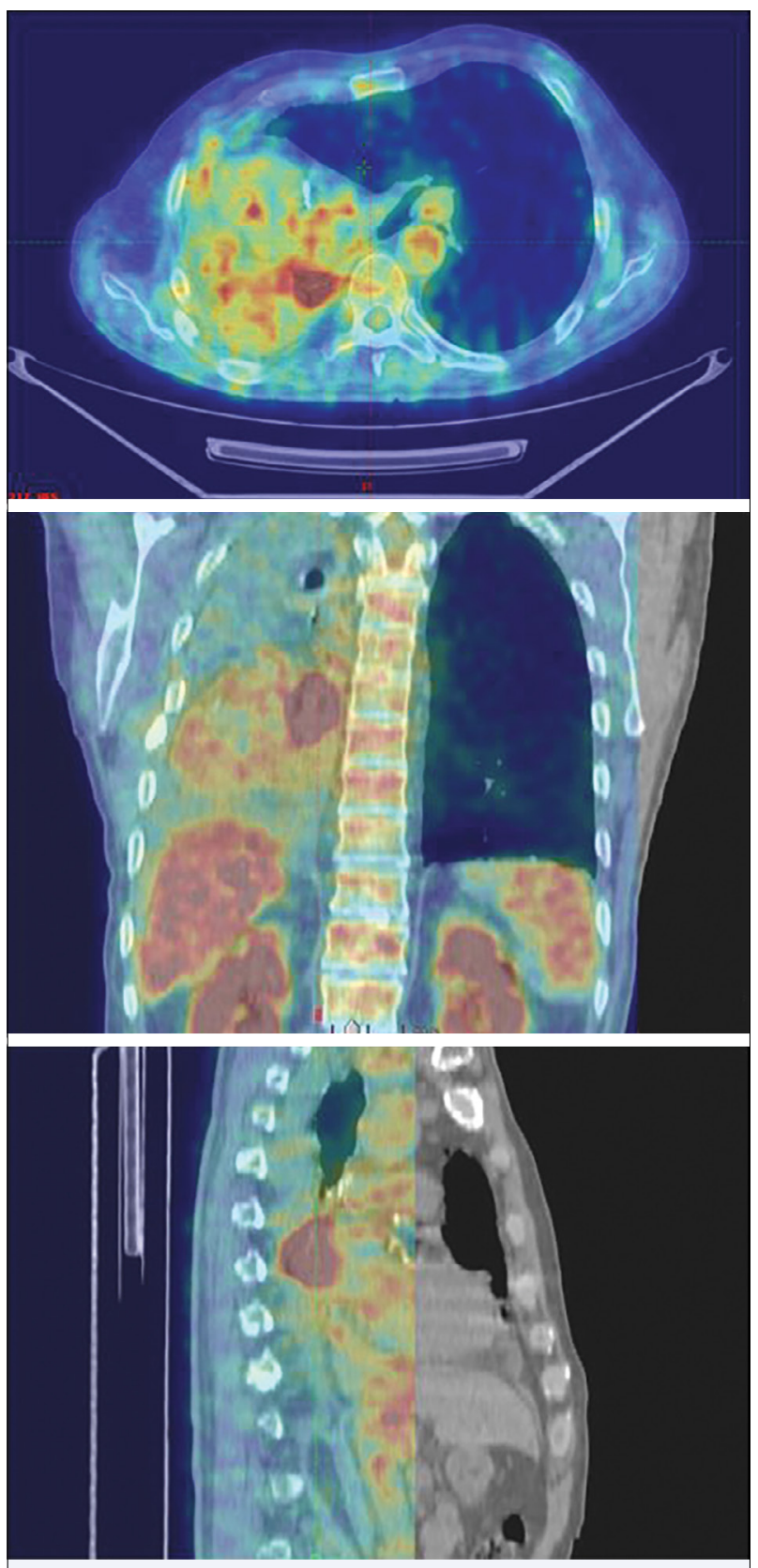

Fig. 1. Positron emission tomography-computed tomography images of the patient before chemoradiotherapy.

MRI after cardiological examination. RT for cardiac metastasis was planned for the patient. Chemotherapy was performed simultaneously with RT (4 cycles of paclitaxel $45 \mathrm{mg} / \mathrm{m}^{2}$ and weekly - carboplatin AUC). The target volume contouring in RT was created using the MRI images together with the radiologist. The movement of the mass in MRI was evaluated by the radiologist and a $5 \mathrm{~mm}$ margin was decided according to his suggestion. CTV margin was not planned due to tumor location and metastatic disease (Fig. 2). Since studies in the literature differed according to patient performance status, radiosensitivity of the primary disease, and concurrent chemotherapy in dose selection, we also considered these factors. Considering the dose limitations of the heart, $46 \mathrm{~Gy}$ RT was planned because the patient's performance status was good, the primary disease was under control, there was no accompanying metastasis, and concurrent chemotherapy was planned. A total of 46 Gy RT was applied with $2 \mathrm{~Gy} /$ fraction (frc) daily. The volumetric arc radiotherapy technique was used and dose-volume values were provided for the heart and lungs in accordance with the QUANTEC dose limits. In the cardiac MRI examination in the $2^{\text {nd }}$ month after RT, $13 \mathrm{~mm}$ was measured in the thickest part of the posterior wall of the left atrium. In comparative evaluation, partial regression was detected (Fig. 3). The patient's last checks were done at post-RT 9 months. Due to a pandemic situation, his last follow-up made through telephone meeting at the post-RT 14 months and he has not had any complaint or symptom.

Metastatic cardiac tumors are observed more frequently than primary malignant tumors of the heart. $[9,10]$ Cardiac metastasis was detected in 8 patients in the autopsy series of 1900 cases, which consisted of people who died due to any cancer.[10] In autopsy series, cardiac metastasis rates are low and reported between $1.5 \%$ and $25 \%$. [2,3,11] This percentage value was found to be higher in autopsy series, especially in cases with widespread metastatic disease.[11] However, as in the current case, isolated cardiac metastasis percentages are quite low and $1.5 \%$ have been reported in a large autopsy series.[4]

Cardiac metastasis rates are higher in hematological malignancies. Solid tumors that metastasize most frequently to heart are melanoma, lung cancer, breast cancer, soft tissue sarcoma, renal cell carcinoma (RCC), esophageal cancer, hepatocellular cancer, and thyroid cancer.[8] In particular, melanomas tend to have cardiac metastases. [3,8]

Lung cancer can cause cardiac involvement through direct invasion, hematogenous, or lymphatic spread. In addition to these three invasions, especially in RCC and hepatocellular carcinoma, cardiac involvement can occur by transvenous route.[7] In this case, all examinations of the patient from the diagnosis were examined together with the radiologist and cardiac metastasis is thought to develop by direct invasion.

The cardiac metastasis can be invaded into different infrastructures of the heart according to its metastasis 


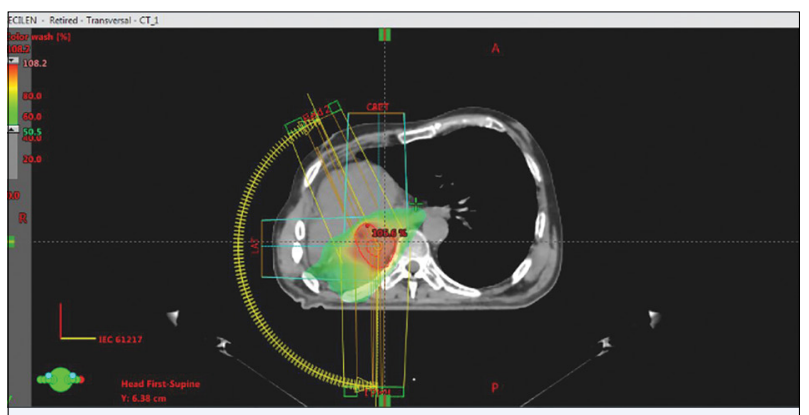

Fig. 2. Radiotherapy plan images of the patient. The green line shows the $50 \%$ isodose area.
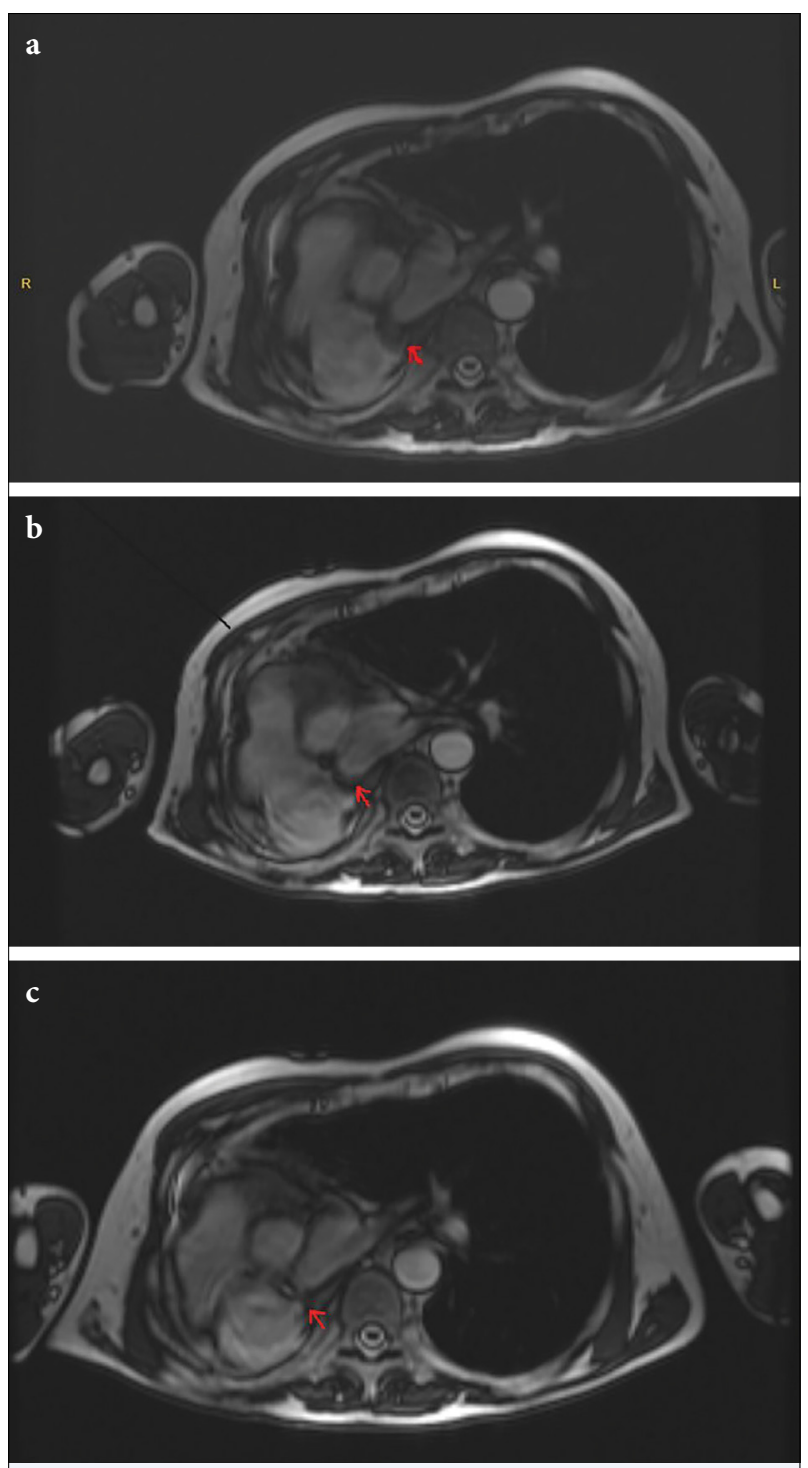

Fig. 3. Magnetic resonance imaging images of the patient before and after chemoradiotherapy. (a) Pre-chemoradiotherapy, (b) post-chemoradiotherapy (CRT) 2 months, (c) post-CRT 4 months. path and may appear with different clinical complaints. The most common involvement is observed in the pericardium. [4,6] In addition, endocardium, myocardium, epicardium, valves, and even left anterior descending artery involvements have been reported.[6] Although cardiac metastases are mostly silent, they can cause different clinical findings depending on the location and severity of involvement. As a result of myocardial involvement, cardiac failure and congestive heart failure may be seen. Pericarditis and pericardial effusion may develop due to pericardial involvement. In the involvement of the valves, the patient's symptoms mimic the stenotic heart valve disease.[12]

The diagnosis of cardiac metastasis can be diagnosed in patients with cardiac symptoms by further examination, without clinical findings in the patient or, with mild-non heart-specific symptoms as in the case we presented, the tests performed for primary cancer follow-up can be detected incidentally. Cardiomegaly due to cardiac involvement can be observed in direct X-ray examinations. Transthoracic echocardiography and transesophageal ultrasound, which are ultrasonic examinations, are mostly performed for symptom research and findings such as mass effect, pericardial effusion can be detected. If cardiac metastasis is suspected as a result of these examinations, the cases are analyzed by further methods.[7]

In suspicious cases, as in our case, the most frequently used examination is the cardiac MRI technique due to its high-resolution quality and superiority in showing soft tissues. Cardiac masses are generally hypointense in $\mathrm{T} 1$ sequence, hyperintense in T2 imaging, and intensely contrasted after contrast injection. In addition to these features of the cardiac MRI, a high $\mathrm{T} 1$ signal is typically observed due to the paramagnetic properties of melanin in malignant melanoma involvement, thus eliminating the need for a biopsy and providing a specific diagnosis for primary malignancy. $[13,14]$ In the current case, cardiac MRI was applied in suspicion of PET-CT findings for follow-up purposes and cardiac involvement was determined.

Cardiac metastases will increasingly appear with the increase in survival in cancer patients and the development of imaging methods. The publications on this subject are generally in the form of case reports. There is no standard approach for cardiac metastases due to many factors such as low incidence, different involvement sites, and varying symptom severity, control of the primary tumor, and the performance of the patient. Surgery and RT are the primary local treatment options presented in case reports. Surgery is generally 
preferred as the primary approach in symptomatic patients and in cases where tumor location is suitable for resection. $[2,3,15]$

In a recent study, Burazor et al. examined cases with cardiac tumors treated at two different centers, $15.8 \%(n=4)$ of cases were found to be metastatic cardiac tumors. Surgical treatment was applied in 3 of the cases and no treatment could be given in one case due to general condition disorder. In this study, although there is a case receiving adjuvant immunotherapy to be suitable for primary tumors, no case of adjuvant RT has been mentioned as in the literature.[15]

$\mathrm{RT}$ is an oncological treatment that can be applied in different doses and schemes for palliative and curative purposes, especially in cases where surgery is not possible. Radiosensitive tumors such as lymphoma respond with lower doses (20 Gy), but higher doses $(45 \pm$ boost) are recommended in more radioresistant tumors.[2] In this case, cardiac metastasis was considered to be inoperable by cardiovascular surgery, the primary disease is under control, the patient's performance score is good, and in addition, the metastasis limits are in a clearly traceable focus.

Case reports involving RT in the treatment of cardiac metastasis in the literature are summarized in Table 1.[16-21] Apart from case reports, small series of cases involving RT in the treatment of cardiac metastasis have also been reported in the literature. In a series of 10 cases which different palliative RT techniques and dosage schedules were applied, the researchers emphasized that effective palliation could be achieved with RT and reported the median response time as 6.3 months. [22] In another study evaluating 11 cardiac metastasis cases with a primary diagnosis of soft tissue sarcoma, RT was applied to 7 of the cases. Median survival was reported to be 10.5 months in cases receiving $\mathrm{RT}$ and 3.5 months in those who did not.[23]

Today, RT is applied with much more modern techniques. Therefore, the decision was to proceed with concurrent chemoradiotherapy using intensity-modulated radiation therapy (IMRT) technique. Cardiac MRI examination was also used for response assessment and evaluation was provided by the same radiologist. In the literature, an IMRT-treated case was reported due to leiomyosarcoma heart metastasis, but RT details were not specified.[16] In another recent study, stereotactic body RT (20 Gy/1 frc) was used to treat cardiac metastasis curatively using by CyberKnife.[17]

The number of cases in which CRT is evaluated in the treatment of cardiac metastases is very limited. Ac- cording to our screening results, this case is the second study in which CRT for metastatic cardiac tumor is evaluated.

Cardiac metastases are rare in the follow-up of cancer patients and are mostly detected in postmortem studies. The number of cases with cardiac metastasis increases as a result of the advancement of imaging methods, the development of treatment methods, and the increase in survival rates in cancer patients. In these cases, the location of the lesion, the presence of symptoms, the control status of the primary malignancy, and the patient's performance are determinative in the treatment approach. RT may be an effective treatment option for patients with inoperable cardiac metastasis.

\section{References}

1. Yusuf SW, Bathina JD, Qureshi S, Kaynak HE, Banchs J, Trent JC, et al. Cardiac tumors in a tertiary care cancer hospital: Clinical features, echocardiographic findings, treatment and outcomes. Heart Int 2012;7(1):e4.

2. Al-Mamgani A, Baartman L, Baaijens M, de Pree I, Incrocci L, Levendag PC. Cardiac metastases. Int J Clin Oncol 2008;13(4):369-72.

3. Reynen K, Köckeritz U, Strasser RH. Metastases to the heart. Ann Oncol 2004;15(3):375-81.

4. Bussani R, De-Giorgio F, Abbate A, Silvestri F. Cardiac metastases. J Clin Pathol 2007;60(1):27-34.

5. Tesolin M, Lapierre C, Oligny L, Bigras JL, Champagne M. Cardiac metastases from melanoma. Radiographics 2005;25(1):249-53.

6. Butany J, Leong SW, Carmichael K, Komeda M. A 30year analysis of cardiac neoplasms at autopsy. Can J Cardiol 2005;21(8):675-80.

7. Lichtenberger JP $3^{\text {rd }}$, Reynolds DA, Keung J, Keung E, Carter BW. Metastasis to the heart: A radiologic approach to diagnosis with pathologic correlation. AJR Am J Roentgenol 2016;207(4):764-72.

8. Goldberg AD, Blankstein R, Padera RF. Tumors metastatic to the heart. Circulation 2013;128(16):17904.

9. Burazor I, Aviel-Ronen S, Imazio M, Goitein O, Perelman M, Shelestovich N, et al. Metastatic cardiac tumors: From clinical presentation through diagnosis to treatment. BMC Cancer 2018;18(1):202.

10. Silvestri F, Bussani R, Pavletic N, Mannone T. Metastases of the heart and pericardium. G Ital Cardiol 1997;27(12):1252-5.

11. Husain A. Thoracic Pathology. Philadelphia, PA: Saunders; 2012. p. 557-8.

12. Maleszewski JJ, Anavekar NS, Moynihan TJ, Klarich 
KW. Pathology, imaging, and treatment of cardiac tumours. Nat Rev Cardiol 2017;14(9):536-49.

13. Hoey ET, Mankad K, Puppala S, Gopalan D, Sivananthan MU. MRI and CT appearances of cardiac tumours in adults. Clin Radiol 2009;64(12):1214-30.

14. O’Donnell DH, Abbara S, Chaithiraphan V, Yared K, Killeen RP, Cury RC, et al. Cardiac tumors: Optimal cardiac MR sequences and spectrum of imaging appearances. AJR Am J Roentgenol 2009;193(2):377-87.

15. Rosas D, Raez LE. Cardiac tumors are not always myxomas. Ann Clin Case Rep 2020;5:1781.

16. Jumeau R, Vincenti MG, Pruvot E, Schwitter J, Vallet $\mathrm{V}$, Zeverino $\mathrm{M}$, et al. Curative management of a cardiac metastasis from lung cancer revealed by an electrical storm. Clin Transl Radiat Oncol 2020;21:62-5.

17. Frakulli R, Cammelli S, Salvi F, Balestrini D, Baldissera A, Degli Esposti C, et al. Unusual case of spindle cell sarcoma metastases to right ventricle: A case report and a literature review. Ann Transl Med 2017;5(17):344.

18. Lee P, Kishan AU. Radiotherapy is effective for a primary lung cancer invading the left atrium. BMJ Case
Rep 2012;2012:bcr2012006667.

19. Dasgupta T, Barani IJ, Roach M $3^{\text {rd }}$. Successful radiation treatment of anaplastic thyroid carcinoma metastatic to the right cardiac atrium and ventricle in a pacemaker-dependent patient. Radiat Oncol 2011;6:16.

20. Fukuda A, Saito T, Imai M, Ishii K, Miwa K. Metastatic cardiac papillary carcinoma originating from the thyroid in both ventricles with a mobile right ventricular pedunculated tumor. Jpn Circ J 2000;64(11):890-2.

21. Yamana N, Sueyama H, Hamada M. Cardiac metastasis from Merkel cell skin carcinoma. Int J Clin Oncol 2004;9(3):210-2.

22. Fotouhi Ghiam A, Dawson LA, Abuzeid W, Rauth S, Jang RW, Horlick E, et al. Role of palliative radiotherapy in the management of mural cardiac metastases: Who, when and how to treat? A case series of 10 patients. Cancer Med 2016;5(6):989-96.

23. Takenaka S, Hashimoto N, Araki N, Hamada K, Naka $\mathrm{N}$, Joyama $\mathrm{S}$, et al. Eleven cases of cardiac metastases from soft-tissue sarcomas. Jpn J Clin Oncol 2011;41(4):514-8. 